\title{
Reporting guidelines for oncology research: helping to maximise the impact of your research
}

\author{
Angela MacCarthy ${ }^{\star}, 1$, Shona Kirtley ${ }^{1}$, Jennifer A de Beyer ${ }^{1}$, Douglas G Altman ${ }^{1}$ and Iveta Simera ${ }^{1}$ \\ ${ }^{1}$ UK EQUATOR Centre, Centre for Statistics in Medicine, Nuffield Department of Orthopaedics, Rheumatology and \\ Musculoskeletal Sciences, University of Oxford, Botnar Research Centre, Windmill Road, Headington, Oxford OX3 7LD, UK
}

Many reports of health research omit important information needed to assess their methodological robustness and clinical relevance. Without clear and complete reporting, it is not possible to identify flaws or biases, reproduce successful interventions, or use the findings in systematic reviews or meta-analyses. The EQUATOR Network (http://www.equator-network.org/) promotes responsible reporting and the use of reporting guidelines to improve the accuracy, completeness, and transparency of health research. EQUATOR supports researchers by providing online resources and training. EQUATOR Oncology, a project funded by Cancer Research UK, aims to support cancer researchers reporting their research through the provision of online resources. In this article, our objective is to highlight reporting issues related to oncology research publications and to introduce reporting guidelines that are designed to aid high-quality reporting. We describe generic reporting guidelines for the main study types, and explain how these guidelines should and should not be used. We also describe 37 oncology-specific reporting guidelines, covering different clinical areas (e.g., haematology or urology) and sections of the report (e.g., methods or study characteristics); most of these are little-used. We also provide some background information on EQUATOR Oncology, which focuses on addressing the reporting needs of the oncology research community.

Health research studies must be reported clearly, accurately, and completely if they are to meaningfully enhance medical knowledge and inform clinical practice. Ambiguous, missing, or misleading information obscures how research was carried out and what was found, limiting critical assessment and impeding further use of published findings. It also wastes the financial and human resources invested in the research (Glasziou et al, 2014).

Readers cannot judge the robustness of the methodology used or the reliability of the findings if study methods are reported badly. Further, other researchers may be prevented from repeating the study (Goodman et al, 2016). Poor reporting of clinical details, inconsistent use of terminology and definitions, insufficient information about interventions, incomplete details of statistical methods, and inconsistent or missing reporting of adverse effects also hamper comparisons of findings across studies, which are necessary to determine the best options for patient care and disease prevention.

Oncology research suffers from the reporting inadequacies that afflict all health research. Table 1 gives some examples of the consequences of poor reporting in different study types in oncology.

Despite early calls by the World Health Organization (Unknown, 1979) and others (Nahum, 1979; Miller et al, 1981) to standardise how the results of cancer treatment studies are reported, many recent studies evaluating the quality of oncology clinical trial reporting have found biased and inconsistent reporting to be very common (Duff et al, 2010; Peron et al, 2012; Vera-Badillo et al, 2016). Basing decisions about patient care on incomplete and misleading research findings may have a profoundly negative impact on patients' health and wellbeing.

These reporting problems are avoidable. In this paper, we introduce reporting guidelines - simple but effective tools supporting complete and transparent reporting - and highlight guidelines that are specifically useful for oncology research. We introduce the EQUATOR (Enhancing the QUAlity and Transparency Of health Research) Network programme, its online resources, and a new project, EQUATOR Oncology, which is collating oncology-specific resources. 
Table 1. Examples of reporting problems in oncology studies

\begin{tabular}{|c|c|c|c|}
\hline Reporting issue & Examples of poor reporting & Consequences of poor reporting & Reference \\
\hline \multicolumn{4}{|c|}{ Observational studies } \\
\hline $\begin{array}{l}\text { Prognostic studies } \\
\text { not published }\end{array}$ & Completed prognostic studies of biomarkers not published. & $\begin{array}{l}\text { Conclusions drawn from systematic reviews may be } \\
\text { inaccurate due to the evidence base not being complete } \\
\text { (likely publication bias). }\end{array}$ & $\begin{array}{l}\text { Sekula et al } \\
\text { (2016) }\end{array}$ \\
\hline $\begin{array}{l}\text { Epidemiological } \\
\text { studies: incomplete } \\
\text { reporting of } \\
\text { methodology }\end{array}$ & $\begin{array}{l}\text { Under-reporting of methodological aspects of observational } \\
\text { studies including: matching, absolute risks, lack of flow } \\
\text { diagram and missing data. }\end{array}$ & Difficult for readers to assess the validity of the studies. & $\begin{array}{l}\text { Papathana- } \\
\text { siou and } \\
\text { Zintzaras } \\
(2010)\end{array}$ \\
\hline $\begin{array}{l}\text { Prognostic factor } \\
\text { studies: methods } \\
\text { poorly reported }\end{array}$ & $\begin{array}{l}\text { Inadequate reporting of aspects of study design and } \\
\text { implementation in studies of prognostic markers, including: } \\
\text { power calculations, time of enrolment, lists of candidate } \\
\text { variables, definition of outcomes and providing the assay } \\
\text { reference. }\end{array}$ & $\begin{array}{l}\text { Studies are often too small to detect modest effects, and } \\
\text { results from a number of studies may be examined together } \\
\text { in systematic reviews or meta-analyses. If methods and } \\
\text { findings are not reported in sufficient detail, it is not possible } \\
\text { to include studies in such reviews. }\end{array}$ & $\begin{array}{l}\text { Kyzas et al } \\
(2007)\end{array}$ \\
\hline \multicolumn{4}{|c|}{ Clinical trials: results } \\
\hline $\begin{array}{l}\text { Results not } \\
\text { published }\end{array}$ & $\begin{array}{l}\text { Trial findings that have been presented at professional } \\
\text { meetings remain unreported or there is a delay in reporting. }\end{array}$ & $\begin{array}{l}\text { Publication bias limits the available evidence base and, if } \\
\text { decision to not publish is driven by results, distorts the overall } \\
\text { evidence picture (likely publication bias). This can lead to } \\
\text { treatments being used based on overoptimistic published } \\
\text { results. }\end{array}$ & $\begin{array}{l}\text { Tam et al } \\
\text { (2011) }\end{array}$ \\
\hline $\begin{array}{l}\text { Inconsistencies } \\
\text { within publications }\end{array}$ & $\begin{array}{l}\text { Differences between reporting in abstracts and the main } \\
\text { body of the text of the published articles: for example, strong } \\
\text { support for the experimental arm of the study in the abstract, } \\
\text { but not in the main text of the report. }\end{array}$ & $\begin{array}{l}\text { Busy clinicians and policymakers may only read the abstract } \\
\text { of the article. Reading only the published abstract may lead } \\
\text { to a distorted view of the overall study findings, with } \\
\text { implications for physicians when making decisions about } \\
\text { clinical care. }\end{array}$ & $\begin{array}{l}\text { Altwairgi } \\
\text { et al (2012) }\end{array}$ \\
\hline \multirow[t]{2}{*}{$\begin{array}{l}\text { Data published but } \\
\text { with deficiencies }\end{array}$} & $\begin{array}{l}\text { Poor reporting of adverse event collection, description of } \mathrm{AE} \\
\text { characteristics leading to withdrawals, and whether AEs were } \\
\text { attributed to trial interventions. }\end{array}$ & $\begin{array}{l}\text { If information about effects of complex, (often combined) } \\
\text { therapies are unavailable, could invalidate the decision- } \\
\text { making process for clinicians and their patients. }\end{array}$ & $\begin{array}{l}\text { Peron et al } \\
(2013)\end{array}$ \\
\hline & $\begin{array}{l}\text { Poor reporting of adverse events in surgery, lack of } \\
\text { standardised description of adverse events. }\end{array}$ & $\begin{array}{l}\text { Physicians cannot assess the benefits and risks to patients } \\
\text { that are likely to be offered surgery. }\end{array}$ & $\begin{array}{l}\text { Meghelli } \\
\text { et al (2016) }\end{array}$ \\
\hline \multirow[t]{2}{*}{$\begin{array}{l}\text { Poor reporting of } \\
\text { trial outcomes }\end{array}$} & $\begin{array}{l}\text { Trial outcomes: Selective trial outcome reporting, such as a } \\
\text { discrepancy between the planned and published primary trial } \\
\text { endpoints. Lack of reporting of planned non-primary trial } \\
\text { endpoints. }\end{array}$ & $\begin{array}{l}\text { Difficult to reproduce studies with poor reporting of } \\
\text { outcomes. Overestimation of intervention effect sizes, which } \\
\text { has an impact on evidence-based clinical decision making. }\end{array}$ & $\begin{array}{l}\text { Raghav et al } \\
\text { (2015) }\end{array}$ \\
\hline & $\begin{array}{l}\text { Patient-reported outcomes (PROs), quality of life: Poor } \\
\text { reporting of methods of PRO collection and analysis, the pre- } \\
\text { specified PRO hypothesis, methods for PRO collection and } \\
\text { statistical approaches for dealing with missing data. }\end{array}$ & $\begin{array}{l}\text { Patient-reported outcomes are essential in oncology trials. In } \\
\text { conjunction with primary outcomes, such as survival, to allow } \\
\text { the assessment of benefits and harms associated with the } \\
\text { treatment. They are the 'voice' of the patients in the trial and } \\
\text { therefore provide a unique perspective on the treatment; } \\
\text { they should be addressed in the trial report. }\end{array}$ & $\begin{array}{l}\text { Bylicki et al } \\
(2015)\end{array}$ \\
\hline \multicolumn{4}{|c|}{ Clinical trials: methods } \\
\hline & $\begin{array}{l}\text { Trial interventions - Chemotherapy: Poor reporting of the } \\
\text { relative dose intensity, dose modification, early treatment } \\
\text { discontinuation. }\end{array}$ & $\begin{array}{l}\text { Replication and translation into clinical practice is impossible } \\
\text { if there is not detailed information on the treatment } \\
\text { administered under trial conditions. }\end{array}$ & $\begin{array}{l}\text { Altwairgi } \\
\text { et al (2015) }\end{array}$ \\
\hline
\end{tabular}

\section{THE EQUATOR NETWORK}

The EQUATOR Network was set up in 2006 to support the implementation of reporting guidelines. Along with its database of reporting guidelines, the EQUATOR programme provides resources and toolkits to help researchers write complete and transparent health research papers. Resources are also provided for journal editors and peer reviewers to help ensure that published research is 'fit for purpose', that is, that it provides all of the information needed for its assessment and further use. The Network also organises events and conferences to raise awareness of poor reporting and its consequences, and offers training for researchers and editors to maximise the value of their published research. Ongoing work is expanding the scope of EQUATOR's resources to also cover guidance for research planning. More information about the EQUATOR Network is available on our website (http://www.equator-network.org/ about-us/).
EQUATOR's scope is primarily studies of humans and preclinical animal research. We do not address laboratory research. Related resources for such research tend to target data sharing, such as MIAME for microarray experiments (Brazma et al, 2001; https://fairsharing.org/).

\section{REPORTING GUIDELINES}

Reporting guidelines provide one solution to the widespread problems in research reporting. They are simple, efficient tools, most often in the form of a checklist, that help researchers to prepare manuscripts that contain all of the information required by readers and those that will use the research report.

Table 2 lists the generic guidelines for the main research study types. Most of these guidelines provide a reporting framework for a whole research paper and list the minimum information that authors should include within the paper so that their study can be 
Table 2. Generic reporting guidelines available in the EQUATOR Network database of reporting guidelines

\begin{tabular}{|c|c|c|}
\hline Guideline abbreviation & Scope of reporting guideline & $\begin{array}{l}\text { Link to further details about the guideline in the } \\
\text { EQUATOR Network database }\end{array}$ \\
\hline CONSORT & Parallel group randomised trials (extensions address other designs) & $\begin{array}{l}\text { Schulz et al, 2010, http://www.equator-network.org/ } \\
\text { reporting-guidelines/consort/ }\end{array}$ \\
\hline STROBE & $\begin{array}{l}\text { Observational studies in epidemiology: cohort, case-control studies, } \\
\text { cross-sectional studies }\end{array}$ & $\begin{array}{l}\text { von Elm et al, 2007, http://www.equator-network.org/ } \\
\text { reporting-guidelines/strobe/ }\end{array}$ \\
\hline PRISMA & $\begin{array}{l}\text { Systematic reviews and meta-analyses (in particular of randomised } \\
\text { trials) }\end{array}$ & $\begin{array}{l}\text { Moher et al, 2009, http://www.equator-network.org/ } \\
\text { reporting-guidelines/prisma/ }\end{array}$ \\
\hline CARE & Clinical case reports & $\begin{array}{l}\text { Gagnier et al, 2014, http://www.equator-network.org/ } \\
\text { reporting-guidelines/care/ }\end{array}$ \\
\hline SRQR & Qualitative research & $\begin{array}{l}\text { O'Brien et al, 2014, http://www.equator-network.org/ } \\
\text { reporting-guidelines/srqr/ }\end{array}$ \\
\hline COREQ & Qualitative research interviews and focus groups & $\begin{array}{l}\text { Tong et al, 2007, http://www.equator-network.org/ } \\
\text { reporting-guidelines/coreq/ }\end{array}$ \\
\hline STARD & Diagnostic test accuracy studies & $\begin{array}{l}\text { Bossuyt et al, 2015, http://www.equator-network.org/ } \\
\text { reporting-guidelines/stard/ }\end{array}$ \\
\hline TRIPOD & $\begin{array}{l}\text { Studies developing, validating, or updating a prediction model, for } \\
\text { either diagnosis or prognosis }\end{array}$ & $\begin{array}{l}\text { Collins et al, 2015, http://www.equator-network.org/ } \\
\text { reporting-guidelines/tripod-statement/ }\end{array}$ \\
\hline REMARK & Tumour marker prognostic studies & $\begin{array}{l}\text { McShane et al, 2005, http://www.equator-network.org/ } \\
\text { reporting-guidelines/reporting-recommendations-for- } \\
\text { tumour-marker-prognostic-studies-remark/ }\end{array}$ \\
\hline SQUIRE & Quality improvement in health care & $\begin{array}{l}\text { Ogrinc et al, 2016, http://www.equator-network.org/ } \\
\text { reporting-guidelines/squire/ }\end{array}$ \\
\hline CHEERS & Economic evaluations of health interventions & $\begin{array}{l}\text { Husereau et al, 2013, http://www.equator-network.org/ } \\
\text { reporting-guidelines/cheers/ }\end{array}$ \\
\hline ARRIVE & Bioscience research using laboratory animals & $\begin{array}{l}\text { Kilkenny et al, 2012, http://www.equator-network.org/ } \\
\text { reporting-guidelines/improving-bioscience-research- } \\
\text { reporting-the-arrive-guidelines-for-reporting-animal- } \\
\text { research/ }\end{array}$ \\
\hline SPIRIT & Clinical trial protocols & $\begin{array}{l}\text { Chan et al, 2013, http://www.equator-network.org/ } \\
\text { reporting-guidelines/spirit-2013-statement-defining- } \\
\text { standard-protocol-items-for-clinical-trials/ }\end{array}$ \\
\hline PRISMA-P & Systematic reviews and meta-analysis protocols & $\begin{array}{l}\text { Moher et al, 2015, http://www.equator-network.org/ } \\
\text { reporting-guidelines/prisma-protocols/ }\end{array}$ \\
\hline
\end{tabular}

fully understood, replicated if desired, and used to inform future research. Some of these guidelines also have extensions, offering additional guidance. The guidelines can also be used by peer reviewers to check that research reports are complete, accurate reflections of the research undertaken (Levine and Kressel, 2016).

The best known guidelines are the CONSORT Statement (checklist shown in Supplementary File 1) for reporting randomised controlled trials (Schulz et al, 2010) and the STROBE Statement (checklist shown in Supplementary File 2) for reporting observational studies (von Elm et al, 2007). Although reporting guidelines should not be used to critically appraise reports of research studies, they prompt authors to report the information needed for a complete critical appraisal.

Generic guidelines exist for reporting most major types of clinical and pre-clinical research. They provide an excellent starting point when writing up any study, including oncology research. Other reporting guidelines that provide guidance on reporting specific aspects of study methods, procedures, or medical conditions, including oncology-specific guidelines, can be found in the database of reporting guidelines on the EQUATOR Network website. The Network systematically collects and classifies all reporting guidelines to help researchers easily find the guidelines relevant to their work.

There is increasing interest in the publication of protocols for research studies. Guidelines are available for preparing protocols for randomised trials (Chan et al, 2013) and systematic reviews (Moher et al, 2015).

\section{EQUATOR ONCOLOGY}

The UK EQUATOR Centre was awarded funding from Cancer Research UK to develop oncology-specific resources and activities to enhance the quality and transparency of published oncology research (http://www.equator-network.org/library/equator-oncology/).

We are reviewing the literature on the quality of reporting of clinical trials and observational studies in oncology. In the course of our work, we are collating published literature on oncology research methodology and reporting, which we regularly make available through the EQUATOR Oncology Current Awareness Bulletin.

The project focuses on research reporting, but in the next phase will be expanded to include guidance for efficient research planning and design. Ensuring robustness in the planning of any research project is the first condition for obtaining reliable research findings. For example, writing a detailed protocol documenting the study design and all methods forms the basis for the final written research manuscript. Guidelines already exist for preparing some types of research protocol, each linked with corresponding guidelines for reporting study findings. For example, the SPIRIT checklist (Chan et al, 2013) is used to guide the preparation of a protocol for a randomised controlled trial, with much overlap of concepts and structure with the CONSORT checklist (Schulz et al, 2010) for reporting trial findings. 
Table 3. Oncology-specific reporting guidelines available on the EQUATOR website

\section{Guideline provided for}

\section{Clinical area of study that guideline relates to}

Section of study report that guideline relates to
No of citations of guideline
Guideline Guideline reference and link to available more information about the via 'Open guideline in the EQUATOR Access' database [number]

(a) Guidance for reporting all parts of a study

\begin{tabular}{|c|c|}
\hline 1. Clinical trials & \\
\hline Myeloma clinical trials & Oncology, haematology \\
\hline $\begin{array}{l}\text { Phase } 1 \text { and phase } 2 \text { clinical trials in } \\
\text { neuro-oncology }\end{array}$ & Oncology, neurology \\
\hline $\begin{array}{l}\text { Surgically-based therapeutic clinical } \\
\text { trials }\end{array}$ & $\begin{array}{l}\text { Oncology, neurology, } \\
\text { surgery }\end{array}$ \\
\hline $\begin{array}{l}\text { Therapeutic trials in acute myeloid } \\
\text { leukaemia (AML) }\end{array}$ & Oncology, haematology \\
\hline $\begin{array}{l}\text { Clinical trials in cancer pain } \\
\text { educational interventions }\end{array}$ & Oncology \\
\hline 2. Observational studies & \\
\hline Tumour marker prognostic studies & Oncology, genetics \\
\hline $\begin{array}{l}\text { The design and analysis of } \\
\text { prognostic factor studies in non- } \\
\text { small cell lung cancer (NSCLC) }\end{array}$ & $\begin{array}{l}\text { Oncology, genetics, } \\
\text { respiratory medicine }\end{array}$ \\
\hline
\end{tabular}

\begin{tabular}{|l|l|l|l|}
\hline Whole report & 186 & Yes & Rajkumar et al, 2011 [1] \\
\hline Whole report & 16 & Yes & Chang et al, 2005 [2] \\
\hline Whole report & 8 & & Chang et al, 2007 [3] \\
\hline Whole report & 1149 & & Cheson et al, 2003 [4] \\
\hline Whole report & 7 & Yes & Stiles et al, 2010 [5] \\
\hline Whole report & 313 & Yes & McShane et al, 2005 [6] \\
\hline Whole report & 151 & Yes & Subramanian and Simon, 2010 [7] \\
\hline & & & \\
\hline
\end{tabular}

\section{(b) Guidance for reporting certain parts of a study}

\begin{tabular}{|c|c|c|c|c|c|}
\hline 1. Clinical trials & & & & & \\
\hline $\begin{array}{l}\text { Reporting of BCR-ABL molecular } \\
\text { testing }\end{array}$ & Oncology, haematology & $\begin{array}{l}\text { Procedure/method, } \\
\text { results }\end{array}$ & 4 & & Akard and Wang, 2011 [8] \\
\hline $\begin{array}{l}\text { Reporting clinical trial results on } \\
\text { electrochemotherapy }\end{array}$ & Oncology & $\begin{array}{l}\text { Procedure/method, study } \\
\text { characteristics, } \\
\text { intervention, results, } \\
\text { data, outcomes, ethical } \\
\text { issues, research } \\
\text { recommendations }\end{array}$ & 4 & Yes & Campana et al, 2016 [9] \\
\hline $\begin{array}{l}\text { Standard definitions and endpoints } \\
\text { for neoadjuvant clinical trials in } \\
\text { breast cancer }\end{array}$ & Oncology & Terminology/definitions & 23 & & Fumagalli et al, 2012 [10] \\
\hline $\begin{array}{l}\text { Clinical trials in systemic light-chain } \\
\text { amyloidosis }\end{array}$ & Oncology, haematology & $\begin{array}{l}\text { Procedure/method, study } \\
\text { characteristics, outcomes }\end{array}$ & 48 & & Comenzo et al, 2012 [11] \\
\hline $\begin{array}{l}\text { Clinical trials for patients in the state } \\
\text { of a rising prostate-specific antigen }\end{array}$ & Oncology, urology & $\begin{array}{l}\text { Study characteristics, } \\
\text { outcomes }\end{array}$ & 121 & Yes & Scher et al, 2004 [12] \\
\hline $\begin{array}{l}\text { Flow cytometry minimal residual } \\
\text { disease analysis and reporting in } \\
\text { multiple myeloma }\end{array}$ & Oncology, haematology & $\begin{array}{l}\text { Procedure/method, } \\
\text { results }\end{array}$ & 3 & Yes & Arroz et al, 2016 [13] \\
\hline $\begin{array}{l}\text { Reporting system for correlation of } \\
\text { cytogenetic and molecular genetic } \\
\text { data with clinical data }\end{array}$ & Oncology, haematology & $\begin{array}{l}\text { Procedure/method, } \\
\text { intervention, outcomes }\end{array}$ & 1094 & Yes & Döhner et al, 2010 [14] \\
\hline $\begin{array}{l}\text { Reporting definitions, } \\
\text { methodological and statistical issues } \\
\text { for phase } 3 \text { clinical trials in chronic } \\
\text { myeloid leukaemia }\end{array}$ & Oncology & $\begin{array}{l}\text { Terminology/definitions, } \\
\text { statistical methods and } \\
\text { analyses }\end{array}$ & 30 & Yes & Guilhot et al, 2012 [15] \\
\hline Clinical platelet transfusion studies & Oncology, haematology & $\begin{array}{l}\text { Procedure/method, } \\
\text { intervention, outcomes, } \\
\text { harms/adverse effects/ } \\
\text { safety data }\end{array}$ & 2 & & Meyer et al, 2013 [16] \\
\hline $\begin{array}{l}\text { Reporting embolisation treatment of } \\
\text { vascular head, neck and brain } \\
\text { tumours }\end{array}$ & $\begin{array}{l}\text { Oncology, neurology, } \\
\text { radiology, surgery }\end{array}$ & Terminology/definitions & 10 & Yes & Duffis et al, 2012 [17] \\
\hline $\begin{array}{l}\text { Reporting MRI evaluation of } \\
\text { response after neoadjuvant } \\
\text { radiotherapy in soft tissue sarcoma }\end{array}$ & Oncology, radiology & Images & 0 & Yes & Messiou et al, 2016 [18] \\
\hline $\begin{array}{l}\text { To promote standardisation and } \\
\text { diminish variations in the } \\
\text { acquisition, interpretation, and } \\
\text { reporting of whole-body MRI scans } \\
\text { for use in advanced prostate cancer }\end{array}$ & $\begin{array}{l}\text { Oncology, urology, } \\
\text { radiology, nuclear } \\
\text { medicine }\end{array}$ & Images & $\begin{array}{l}\text { Reference not } \\
\text { found }\end{array}$ & Yes & Padhani et al, 2017 [19] \\
\hline
\end{tabular}




\section{Table 3. (Continued)}

\begin{tabular}{|c|c|c|c|c|c|}
\hline Guideline provided for & $\begin{array}{l}\text { Clinical area of study } \\
\text { that guideline relates } \\
\text { to }\end{array}$ & $\begin{array}{l}\text { Section of study } \\
\text { report that guideline } \\
\text { relates to }\end{array}$ & $\begin{array}{l}\text { No of } \\
\text { citations of } \\
\text { guideline }\end{array}$ & $\begin{array}{l}\text { Guideline } \\
\text { available } \\
\text { via 'Open } \\
\text { Access' }\end{array}$ & $\begin{array}{l}\text { Guideline reference and link to } \\
\text { more information about the } \\
\text { guideline in the EQUATOR } \\
\text { database [number] }\end{array}$ \\
\hline $\begin{array}{l}\text { Use of historical data for } \\
\text { determining "go/no go" decision } \\
\text { for definitive phase III testing }\end{array}$ & Oncology & Procedure/method, data & 32 & Yes & Vickers et al, 2007 [22] \\
\hline $\begin{array}{l}\text { Common terminology criteria for } \\
\text { paediatric reporting of adverse } \\
\text { events in oncology trials }\end{array}$ & Oncology, paediatrics & $\begin{array}{l}\text { Terminology/definitions, } \\
\text { harms/adverse effects/ } \\
\text { safety data }\end{array}$ & $\begin{array}{l}\text { Reference not } \\
\text { found }\end{array}$ & & Reeve et al, 2017 [23] \\
\hline $\begin{array}{l}\text { Reporting case series of tumours of } \\
\text { the colon and rectum }\end{array}$ & $\begin{array}{l}\text { Oncology, } \\
\text { gastroenterology, surgery }\end{array}$ & $\begin{array}{l}\text { Procedure/method, study } \\
\text { characteristics, } \\
\text { intervention, results, } \\
\text { data, outcomes }\end{array}$ & $\begin{array}{l}\text { Journal } \\
\text { indexed from } \\
2008 \text { onwards }\end{array}$ & & Rubino and Pragnell, 1999 [25] \\
\hline $\begin{array}{l}\text { Reporting of individual MRI studies } \\
\text { in men with prostate cancer on } \\
\text { active surveillance and for reporting } \\
\text { the outcomes of cohorts of men } \\
\text { with prostate cancer having MRI on } \\
\text { active surveillance }\end{array}$ & $\begin{array}{l}\text { Oncology, urology, } \\
\text { radiology }\end{array}$ & Images & $\begin{array}{l}\text { Reference not } \\
\text { found }\end{array}$ & & Moore et al, 2017 [26] \\
\hline \multicolumn{6}{|l|}{ 3. Other study types } \\
\hline $\begin{array}{l}\text { Standards for balanced reporting on } \\
\text { websites and in newspapers }\end{array}$ & $\begin{array}{l}\text { Oncology, obstetrics \& } \\
\text { gynaecology }\end{array}$ & & 12 & & Bodemer et al, 2012 [27] \\
\hline $\begin{array}{l}\text { Reporting clinical studies and } \\
\text { research on the use of ablation } \\
\text { methods for the treatment of } \\
\text { benign bone tumours and } \\
\text { metastases involving bone and soft } \\
\text { tissues beyond the liver and lung }\end{array}$ & Oncology, radiology & $\begin{array}{l}\text { Procedure/method, study } \\
\text { characteristics, } \\
\text { intervention, results, } \\
\text { images, outcomes, } \\
\text { harms/adverse effects/ } \\
\text { safety data } \\
\end{array}$ & 14 & Yes & Callstrom et al, 2009 [30] \\
\hline $\begin{array}{l}\text { Percutaneous thermal ablation of } \\
\text { primary renal cell carcinoma }\end{array}$ & $\begin{array}{l}\text { Oncology, renal } \\
\text { medicine, radiology, } \\
\text { surgery }\end{array}$ & $\begin{array}{l}\text { Procedure/method, study } \\
\text { characteristics, } \\
\text { terminology/definitions, } \\
\text { intervention, images, } \\
\text { outcomes, harms/adverse } \\
\text { effects/safety data }\end{array}$ & 19 & Yes & Clark et al, 2009 [31] \\
\hline $\begin{array}{l}\text { Percutaneous vertebral } \\
\text { augmentation }\end{array}$ & $\begin{array}{l}\text { Oncology, rheumatology, } \\
\text { radiology, surgery }\end{array}$ & $\begin{array}{l}\text { Procedure/method, study } \\
\text { characteristics, } \\
\text { intervention, outcomes, } \\
\text { harms/adverse effects/ } \\
\text { safety data }\end{array}$ & 8 & Yes & Radvany et al, 2009 [32] \\
\hline $\begin{array}{l}\text { Reporting the various aspects of } \\
\text { image-guided ablation therapy }\end{array}$ & Oncology, radiology & \begin{tabular}{|l|} 
Study characteristics, \\
terminology/definitions, \\
intervention, results, \\
images, statistical \\
methods and analyses, \\
outcomes, harms/adverse \\
effects/safety data
\end{tabular} & 101 & Yes & Ahmed et al, 2014 [33] \\
\hline
\end{tabular}


Table 3. (Continued)

\begin{tabular}{|l|l|l|l|l|l|}
\hline Guideline provided for & $\begin{array}{l}\text { Clinical area of study } \\
\text { that guideline relates } \\
\text { to }\end{array}$ & $\begin{array}{l}\text { Section of study } \\
\text { report that guideline } \\
\text { relates to }\end{array}$ & $\begin{array}{l}\text { No of } \\
\text { citations of } \\
\text { guideline }\end{array}$ & $\begin{array}{l}\text { Guideline } \\
\text { available } \\
\text { via 'Open } \\
\text { Access' }\end{array}$ & $\begin{array}{l}\text { Guideline reference and link to } \\
\text { more information about the } \\
\text { guideline in the EQUATOR } \\
\text { database [number] }\end{array}$ \\
\hline $\begin{array}{l}\text { Reporting image-guided irreversible } \\
\text { electroporation ablation therapy }\end{array}$ & Oncology, radiology & $\begin{array}{l}\text { Terminology/definitions, } \\
\text { data, images }\end{array}$ & $\begin{array}{l}\text { Reference not } \\
\text { found }\end{array}$ & Yes & Wendler et al, 2016 [34] \\
\hline $\begin{array}{l}\text { Reporting and gathering data on } \\
\text { dose-volume dependencies of } \\
\text { treatment outcome }\end{array}$ & Oncology & Data & 65 & Yes & Jackson et al, 2010 [35] \\
\hline $\begin{array}{l}\text { Calibration methods in cancer } \\
\text { simulation models }\end{array}$ & Oncology & Procedure/method, data & 38 & & Stout et al, 2009 [36] \\
\hline Reporting HIF-1 $\alpha-T G$ interactions & Oncology, genetics & Data & $\begin{array}{l}\text { Reference not } \\
\text { found }\end{array}$ & Slemc and Kunej, 2016 [37] \\
\hline
\end{tabular}

[1] http://www.equator-network.org/reporting-guidelines/consensus-recommendations-for-the-uniform-reporting-of-clinical-trials-report-of-the-international-myeloma-workshop-consensuspanel-1/

[2] http://www.equator-network.org/reporting-guidelines/gnosis-guidelines-for-neuro-oncology-standards-for-investigational-studies-reporting-of-phase-1-and-phase-2-clinical-trials/ [3] http://www.equator-network.org/reporting-guidelines/gnosis-guidelines-for-neuro-oncology-standards-for-investigational-studies-reporting-of-surgically-based-therapeutic-clinical-trials/ [4] http://www.equator-network.org/reporting-guidelines/revised-recommendations-of-the-international-working-group-for-diagnosis-standardization-of-response-criteria-treatment-outcomes-and-reporting-standards-for-therapeutic-trials-in-acute-myeloid-leuk/

[5] http://www.equator-network.org/reporting-guidelines/clinical-trials-focusing-on-cancer-pain-educational-interventions-core-components-to-include-during-planning-and-reporting/ [6] http://www.equator-network.org/reporting-guidelines/reporting-recommendations-for-tumour-marker-prognostic-studies-remark/

[7] http://www.equator-network.org/reporting-guidelines/gene-expression-based-prognostic-signatures-in-lung-cancer-ready-for-clinical-use/

[8] http://www.equator-network.org/reporting-guidelines/translating-trial-based-molecular-monitoring-into-clinical-practice-importance-of-international-standards-and-practical-considerations-for-community-practitioners/

[9] http://www.equator-network.org/reporting-guidelines/recommendations-for-improving-the-quality-of-reporting-clinical-electrochemotherapy-studies-based-on-qualitative-systematicreview/

[10] http://www.equator-network.org/reporting-guidelines/a-common-language-in-neoadjuvant-breast-cancer-clinical-trials-proposals-for-standard-definitions-and-endpoints/

[11] http://www.equator-network.org/reporting-guidelines/consensus-guidelines-for-the-conduct-and-reporting-of-clinical-trials-in-systemic-light-chain-amyloidosis/

[12] http://www.equator-network.org/reporting-guidelines/eligibility-and-outcomes-reporting-guidelines-for-clinical-trials-for-patients-in-the-state-of-a-rising-prostate-specific-antigen-recommendations-from-the-prostate-specific-antigen-working-group/

[13] http://www.equator-network.org/reporting-guidelines/consensus-guidelines-on-plasma-cell-myeloma-minimal-residual-disease-analysis-and-reporting/

[14] http://www.equator-network.org/reporting-guidelines/diagnosis-and-management-of-acute-myeloid-leukemia-in-adults-recommendations-from-an-international-expert-panel-on-behalfof-the-european-leukemianet/

[15] http://www.equator-network.org/reporting-guidelines/definitions-methodological-and-statistical-issues-for-phase-3-clinical-trials-in-chronic-myeloid-leukemia-a-proposal-by-the-europeanleukemianet/

[16] http://www.equator-network.org/reporting-guidelines/a-reporting-guideline-for-clinical-platelet-transfusion-studies-from-the-best-collaborative/

[17] http://www.equator-network.org/reporting-guidelines/head-neck-and-brain-tumor-embolization-guidelines/

[18] http://www.equator-network.org/reporting-guidelines/evaluation-of-response-after-pre-operative-radiotherapy-in-soft-tissue-sarcomas-the-european-organisation-for-research-and-treatment-of-cancer-soft-tissue-and-bone-sarcoma-group-eortc-stbsg-and-ima/

[19] http://www.equator-network.org/reporting-guidelines/metastasis-reporting-and-data-system-for-prostate-cancer-practical-guidelines-for-acquisition-interpretation-and-reporting-ofwhole-body-magnetic-resonance-imaging-based-evaluations-of-multiorgan-i/

[20] http://www.equator-network.org/reporting-guidelines/standardization-of-pathologic-evaluation-and-reporting-of-postneoadjuvant-specimens-in-clinical-trials-of-breast-cancer-recommendations-from-an-international-working-group/

[21] http://www.equator-network.org/reporting-guidelines/the-standard-of-reporting-of-health-related-quality-of-life-in-clinical-cancer-trials/

[22] http://www.equator-network.org/reporting-guidelines/setting-the-bar-in-phase-ii-trials-the-use-of-historical-data-for-determining-gono-go-decision-for-definitive-phase-iii-testing/

[23]http://www.equator-network.org/reporting-guidelines/eliciting-the-childs-voice-in-adverse-event-reporting-in-oncology-trials-cognitive-interview-findings-from-the-pediatric-patient-

reported-outcomes-version-of-the-common-terminology-criteria-for-adv/

[24] http://www.equator-network.org/reporting-guidelines/missing-covariate-data-within-cancer-prognostic-studies-a-review-of-current-reporting-and-proposed-guidelines/

[25] http://www.equator-network.org/reporting-guidelines/guidelines-for-reporting-case-series-of-tumours-of-the-colon-and-rectum/

[26] http://www.equator-network.org/reporting-guidelines/reporting-magnetic-resonance-imaging-in-men-on-active-surveillance-for-prostate-cancer-the-precise-recommendations-a-reportof-a-european-school-of-oncology-task-force/

[27] http://www.equator-network.org/reporting-guidelines/do-the-media-provide-transparent-health-information-a-cross-cultural-comparison-of-public-information-about-the-hpv-vaccine/

[28] http://www.equator-network.org/reporting-guidelines/research-reporting-standards-for-radioembolization-of-hepatic-malignancies/

[29] http://www.equator-network.org/reporting-guidelines/transcatheter-therapy-for-hepatic-malignancy-standardization-of-terminology-and-reporting-criteria/

[30] http://www.equator-network.org/reporting-guidelines/research-reporting-standards-for-image-guided-ablation-of-bone-and-soft-tissue-tumors/

[31] http://www.equator-network.org/reporting-guidelines/reporting-standards-for-percutaneous-thermal-ablation-of-renal-cell-carcinoma/

[32] http://www.equator-network.org/reporting-guidelines/research-reporting-standards-for-percutaneous-vertebral-augmentation/

[33] http://www.equator-network.org/reporting-guidelines/image-guided-tumor-ablation-standardization-of-terminology-and-reporting-criteria-a-10-year-update/

[34] http://www.equator-network.org/reporting-guidelines/irreversible-electroporation-ire-standardization-of-terminology-and-reporting-criteria-for-analysis-and-comparison/

[35] http://www.equator-network.org/reporting-guidelines/the-lessons-of-quantec-recommendations-for-reporting-and-gathering-data-on-dose-volume-dependencies-of-treatment-outcome/

[36] http://www.equator-network.org/reporting-guidelines/calibration-methods-used-in-cancer-simulation-models-and-suggested-reporting-guidelines/

[37] http://www.equator-network.org/reporting-guidelines/transcription-factor-hif1a-downstream-targets-associated-pathways-polymorphic-hypoxia-response-element-hre-sites-and-initiative-

for-standardization-of-reporting-in-scientific-literature/

A version of Table 3 with active links is provided online as Supplementary Table 1.

\section{ONCOLOGY-SPECIFIC REPORTING GUIDELINES}

The EQUATOR Network website already offers important resources to help authors write up oncology research studies. In October 2016 our regularly updated database of reporting guidelines included 37 oncology-specific guidelines. These guidelines complement the generic guidelines, offering guidance on reporting aspects of various study types, such as observational studies, prognostic and diagnostic studies, and clinical trials.

Table 3 describes the 37 oncology-specific guidelines by the clinical area, study type, and section of the report that they refer to. Some cover oncology studies in general, while others focus on research in certain diagnostic groups, such as cancer of the lung, liver, breast, kidney, bone, and soft tissue. The fields of 
haematology, neuro-oncology, urology, and gastroenterology are well-represented.

\section{USE OF ONCOLOGY-SPECIFIC REPORTING GUIDELINES}

The publication of a reporting guideline will not affect reporting completeness and quality unless researchers working in the field are aware of and use the guideline when they write their manuscripts. We investigated how many times each oncologyspecific reporting guideline had been cited by other research papers. We searched the Web of Science Core Collection Science Citation Index Expanded (SCI-EXPANDED) from inception to the present (last search date 3 November 2016). The results of these citation searches are shown in Table 3.

Two guidelines have each been cited more than 1000 times. Both focus on haematology research, one covering the whole study report for trials in a particular disease (acute myeloid leukaemia, (Cheson et al, 2003)) and the other dealing with a particular kind of data (correlating genetic and clinical data (Döhner et al, 2010)). Five have been cited between 100 and 350 times, and 23 have been cited less than 100 times. One guideline had no citations but was only published in 2016, and six guidelines were not found in the Citation Index.

It is likely that many authors who use a reporting guideline do not actually cite it, and that not all research papers that cite a guideline do so because it was used to help write the paper. Nevertheless, the citation numbers give a rough indication of the use of each guideline in the literature. Many factors will influence the differences between the citation rates of specific guidelines, for example the size of the subspecialty within oncology and when the guideline was published.

Journals have an important role to play in improving reporting of research studies by highlighting the use of reporting guidelines in their instructions to authors. Reporting guidelines can also be very helpful for peer-reviewers. The EQUATOR Network has produced a new toolkit to help journals to publish clear and therefore usable research reports (http://www.equator-network.org/toolkits/using-guidelines-in-journals/).

\section{FUTURE WORK OF EQUATOR ONCOLOGY}

Health research reporting problems have been well-documented in recent years, and oncology research is no exception (Papathanasiou and Zintzaras, 2010; Peron et al, 2012, 2013; Jankova et al, 2015; Maillet et al, 2016; Sivendran and Galsky, 2016). Despite these continuing reporting issues, two specific guidelines for haematology research have been very well cited. The question remains as to why authors do not use existing reporting guidelines. Is it because authors need additional specific guidelines for certain oncology study types, because authors need help to better use existing guidelines (both generic and specific), because they do not think reporting guidelines are worth the effort, or because they are simply unaware that reporting guidelines exist?

EQUATOR Oncology aims to highlight the real-life consequences of poor reporting, to provide resources and to support oncology researchers by helping them to find and use the appropriate reporting guidelines for their research.

Peer-reviewers also play an important role in the process of improving research reporting, and reporting guidelines can be a helpful tool for those reviewing manuscripts prior to publication. However, checking adherence to a reporting guideline can be time-consuming. It may be helpful for guideline developers to produce short lists of items for peer reviewers to focus their attention on.
We will establish an EQUATOR Oncology 'Advisory Group' of experts and opinion leaders in oncology research including clinicians, oncologists, methodologists, editors, Cancer Research UK and EQUATOR representatives - who will oversee and inform the development of the project. Based on our findings from literature reviews and advice from our expert advisory group, we will identify issues and develop oncology-specific online resources to help minimise reporting problems and increase the impact of published oncology research.

We will also carry out surveys of oncology researchers, oncology journal editors and peer reviewers to identify their concerns about reporting in journal articles.

Our web resources can help oncology researchers improve their research reporting in manuscripts and will ultimately help to improve the robustness and reliability of the research itself. Only with the expert help of authors, researchers, methodologists, opinion leaders, and journal editors working in cancer research can our online resources fully address the reporting issues that oncology researchers need assistance with. We encourage those involved in cancer research to contact us with suggestions for the development of these resources.

Cancer patients take part in research studies to try to improve their health conditions and for altruistic reasons (Moorcraft et al, 2016). Their contributions to scientific understanding should not be wasted because the research is poorly conducted, inadequately reported, or even not reported at all. EQUATOR Oncology will support oncology researchers to conduct robust research and to produce research papers that are usable, reproducible, and transparent, recognising the important contributions of all patient participants in research.

\section{ACKNOWLEDGEMENTS}

This work was supported by Cancer Research UK (C5529/ A16895). The work was carried out in the Centre for Statistics in Medicine, Nuffield Department of Orthopaedics, Rheumatology \& Musculoskeletal Sciences, University of Oxford, UK.

\section{CONFLICT OF INTEREST}

The authors declare no conflict of interest.

\section{REFERENCES}

Ahmed M, Solbiati L, Brace CL, Breen DJ, Callstrom MR, Charboneau JW, Chen MH, Choi BI, de Baere T, Dodd 3rd GD, Dupuy DE, Gervais DA, Gianfelice D, Gillams AR, Lee Jr FT, Leen E, Lencioni R, Littrup PJ, Livraghi T, Lu DS, McGahan JP, Meloni MF, Nikolic B, Pereira PL, Liang P, Rhim H, Rose SC, Salem R, Sofocleous CT, Solomon SB, Soulen MC, Tanaka M, Vogl TJ, Wood BJ, Goldberg SN (2014) Image-guided tumor ablation: standardization of terminology and reporting criteria - a 10-year update. Radiology 273(1): 241-260.

Akard LP, Wang YL (2011) Translating trial-based molecular monitoring into clinical practice: importance of international standards and practical considerations for community practitioners. Clin Lymphoma Myeloma Leuk 11(5): 385-395.

Altwairgi AK, Alfakeeh AH, Hopman WM, Parulekar WR (2015) Quality of reporting of chemotherapy compliance in randomized controlled trials of breast cancer treatment. Jpn J Clin Oncol 45(6): 520-526.

Altwairgi AK, Booth CM, Hopman WM, Baetz TD (2012) Discordance between conclusions stated in the abstract and conclusions in the article: analysis of published randomized controlled trials of systemic therapy in lung cancer. J Clin Oncol 30(28): 3552-3557.

Arroz M, Came N, Lin P, Chen W, Yuan C, Lagoo A, Monreal M, de Tute R, Vergilio JA, Rawstron AC, Paiva B (2016) Consensus guidelines on plasma 
cell myeloma minimal residual disease analysis and reporting. Cytometry $B$ Clin Cytom 90(1): 31-39.

Bodemer N, Muller SM, Okan Y, Garcia-Retamero R, Neumeyer-Gromen A (2012) Do the media provide transparent health information? A crosscultural comparison of public information about the HPV vaccine. Vaccine 30(25): 3747-3756.

Bossuyt PM, Reitsma JB, Bruns DE, Gatsonis CA, Glasziou PP, Irwig L, Lijmer JG, Moher D, Rennie D, de Vet HC, Kressel HY, Rifai N, Golub RM, Altman DG, Hooft L, Korevaar DA, Cohen JF (2015) STARD 2015: an updated list of essential items for reporting diagnostic accuracy studies. Radiology 277(3): 826-832.

Brazma A, Hingamp P, Quackenbush J, Sherlock G, Spellman P, Stoeckert C, Aach J, Ansorge W, Ball CA, Causton HC, Gaasterland T, Glenisson P, Holstege FC, Kim IF, Markowitz V, Matese JC, Parkinson H, Robinson A, Sarkans U, Schulze-Kremer S, Stewart J, Taylor R, Vilo J, Vingron M (2001) Minimum information about a microarray experiment (MIAME)-toward standards for microarray data. Nat Genet 29(4): 365-371.

Brown DB, Gould JE, Gervais DA, Goldberg SN, Murthy R, Millward SF, Rilling WS, Geschwind JF, Salem R, Vedantham S, Cardella JF, Soulen MC, Society of Interventional Radiology Technology Assessment Cthe International Working Group on Image-Guided Tumor A (2009) Transcatheter therapy for hepatic malignancy: standardization of terminology and reporting criteria. J Vasc Interv Radiol 20(7 Suppl): S425-S434.

Burton A, Altman DG (2004) Missing covariate data within cancer prognostic studies: a review of current reporting and proposed guidelines. Br J Cancer 91(1): 4-8.

Bylicki O, Gan HK, Joly F, Maillet D, You B, Peron J (2015) Poor patientreported outcomes reporting according to CONSORT guidelines in randomized clinical trials evaluating systemic cancer therapy. Ann Oncol 26(1): 231-237.

Callstrom MR, York JD, Gaba RC, Gemmete JJ, Gervais DA, Millward SF, Brown DB, Dupuy D, Goldberg SN, Kundu S, Rose SC, Thomas JJ, Cardella JF, Technology Assessment Committee of Society of Interventional R (2009) Research reporting standards for image-guided ablation of bone and soft tissue tumors. J Vasc Interv Radiol 20(12): $1527-1540$.

Campana LG, Clover AJ, Valpione S, Quaglino P, Gehl J, Kunte C, Snoj M, Cemazar M, Rossi CR, Miklavcic D, Sersa G (2016) Recommendations for improving the quality of reporting clinical electrochemotherapy studies based on qualitative systematic review. Radiol Oncol 50(1): 1-13.

Chan AW, Tetzlaff JM, Altman DG, Laupacis A, Gotzsche PC, Krleza-Jeric K, Hrobjartsson A, Mann H, Dickersin K, Berlin JA, Dore CJ, Parulekar WR, Summerskill WS, Groves T, Schulz KF, Sox HC, Rockhold FW, Rennie D, Moher D (2013) SPIRIT 2013 statement: defining standard protocol items for clinical trials. Ann Intern Med 158(3): 200-207.

Chang S, Vogelbaum M, Lang FF, Haines S, Kunwar S, Chiocca EA, Olivi A, Quinones-Hinojosa A, Parsa A, Warnick R (2007) GNOSIS: guidelines for neuro-oncology: standards for investigational studiesreporting of surgically based therapeutic clinical trials. J Neurooncol 82(2): 211-220.

Chang SM, Reynolds SL, Butowski N, Lamborn KR, Buckner JC, Kaplan RS, Bigner DD (2005) GNOSIS: guidelines for neuro-oncology: standards for investigational studies-reporting of phase 1 and phase 2 clinical trials. Neuro Oncol 7(4): 425-434.

Cheson BD, Bennett JM, Kopecky KJ, Buchner T, Willman CL, Estey EH, Schiffer CA, Doehner H, Tallman MS, Lister TA, Lo-Coco F, Willemze R, Biondi A, Hiddemann W, Larson RA, Lowenberg B, Sanz MA, Head DR, Ohno R, Bloomfield CD (2003) Revised recommendations of the International Working Group for Diagnosis, Standardization of Response Criteria, Treatment Outcomes, and Reporting Standards for Therapeutic Trials in Acute Myeloid Leukemia. J Clin Oncol 21(24): 4642-4649.

Clark TW, Millward SF, Gervais DA, Goldberg SN, Grassi CJ, Kinney TB, Phillips DA, Sacks D, Cardella JF, Technology Assessment Committee of the Society of Interventional R (2009) Reporting standards for percutaneous thermal ablation of renal cell carcinoma. J Vasc Interv Radiol 20(7 Suppl): S409-S416.

Collins GS, Reitsma JB, Altman DG, Moons KG (2015) Transparent reporting of a multivariable prediction model for Individual Prognosis or Diagnosis (TRIPOD): the TRIPOD statement. Ann Intern Med 162(1): $55-63$.
Comenzo RL, Reece D, Palladini G, Seldin D, Sanchorawala V, Landau H, Falk R, Wells K, Solomon A, Wechalekar A, Zonder J, Dispenzieri A, Gertz M, Streicher H, Skinner M, Kyle RA, Merlini G (2012) Consensus guidelines for the conduct and reporting of clinical trials in systemic lightchain amyloidosis. Leukemia 26(11): 2317-2325.

Döhner H, Estey EH, Amadori S, Appelbaum FR, Buchner T, Burnett AK, Dombret H, Fenaux P, Grimwade D, Larson RA, Lo-Coco F, Naoe T, Niederwieser D, Ossenkoppele GJ, Sanz MA, Sierra J, Tallman MS, Lowenberg B, Bloomfield CD (2010) Diagnosis and management of acute myeloid leukemia in adults: recommendations from an international expert panel, on behalf of the European LeukemiaNet. Blood 115(3): 453-474.

Duff JM, Leather H, Walden EO, LaPlant KD, George TJ Jr (2010) Adequacy of published oncology randomized controlled trials to provide therapeutic details needed for clinical application. J Natl Cancer Inst 102(10): 702-705.

Duffis EJ, Gandhi CD, Prestigiacomo CJ, Abruzzo T, Albuquerque F, Bulsara KR, Derdeyn CP, Fraser JF, Hirsch JA, Hussain MS, Do HM, Jayaraman MV, Meyers PM, Narayanan S (2012) Head, neck, and brain tumor embolization guidelines. J Neurointerv Surg 4(4): 251255.

Fumagalli D, Bedard PL, Nahleh Z, Michiels S, Sotiriou C, Loi S, Sparano JA, Ellis M, Hylton N, Zujewski JA, Hudis C, Esserman L, Piccart M (2012) A common language in neoadjuvant breast cancer clinical trials: proposals for standard definitions and endpoints. Lancet Oncol 13(6): e240-e248.

Gagnier JJ, Kienle G, Altman DG, Moher D, Sox H, Riley D (2014) The CARE guidelines: consensus-based clinical case report guideline development. J Clin Epidemiol 67(1): 46-51.

Glasziou P, Altman DG, Bossuyt P, Boutron I, Clarke M, Julious S, Michie S, Moher D, Wager E (2014) Reducing waste from incomplete or unusable reports of biomedical research. Lancet 383(9913): 267-276.

Goodman SN, Fanelli D, Ioannidis JP (2016) What does research reproducibility mean? Sci Transl Med 8(341): 341ps12.

Guilhot J, Baccarani M, Clark RE, Cervantes F, Guilhot F, Hochhaus A, Kulikov S, Mayer J, Petzer AL, Rosti G, Rousselot P, Saglio G, Saussele S, Simonsson B, Steegmann JL, Zaritskey A, Hehlmann R (2012) Definitions, methodological and statistical issues for phase 3 clinical trials in chronic myeloid leukemia: a proposal by the European LeukemiaNet. Blood 119(25): 5963-5971.

Husereau D, Drummond M, Petrou S, Carswell C, Moher D, Greenberg D, Augustovski F, Briggs AH, Mauskopf J, Loder E (2013) Consolidated Health Economic Evaluation Reporting Standards (CHEERS) statement. BMC Med 11: 80.

Jackson A, Marks LB, Bentzen SM, Eisbruch A, Yorke ED, Ten Haken RK, Constine LS, Deasy JO (2010) The lessons of QUANTEC: recommendations for reporting and gathering data on dose-volume dependencies of treatment outcome. Int J Radiat Oncol Biol Phys 76(3 Suppl): S155-S160.

Jankova L, Dent OF, Molloy MP, Chan C, Chapuis PH, Howell VM, Clarke SJ (2015) Reporting in studies of protein biomarkers of prognosis in colorectal cancer in relation to the REMARK guidelines. Proteomics Clin Appl 9(11-12): 1078-1086.

Kilkenny C, Browne WJ, Cuthill IC, Emerson M, Altman DG (2012) Improving bioscience research reporting: the ARRIVE guidelines for reporting animal research. Osteoarthritis Cartilage 20(4): 256-260.

Kyzas PA, Denaxa-Kyza D, Ioannidis JP (2007) Quality of reporting of cancer prognostic marker studies: association with reported prognostic effect. J Natl Cancer Inst 99(3): 236-243.

Lee CW, Chi KN (2000) The standard of reporting of health-related quality of life in clinical cancer trials. J Clin Epidemiol 53(5): 451-458.

Levine D, Kressel HY (2016) 2016: reviewing for radiology - reporting guidelines and why we use them. Radiology 280(3): 659-662.

Maillet D, Blay JY, You B, Rachdi A, Gan HK, Peron J (2016) The reporting of adverse events in oncology phase III trials: a comparison of the current status versus the expectations of the EORTC members. Ann Oncol 27(1): 192-198.

McShane LM, Altman DG, Sauerbrei W, Taube SE, Gion M, Clark GM (2005) REporting recommendations for tumour MARKer prognostic studies (REMARK). Br J Cancer 93(4): 387-391.

Meghelli L, Narducci F, Mariette C, Piessen G, Vanseymortier M, Leblanc E, Collinet P, Duhamel A, Penel N (2016) Reporting adverse events in cancer surgery randomized trials: a systematic review of published trials in 
oesophago-gastric and gynecological cancer patients. Crit Rev Oncol Hematol 104: 108-114.

Messiou C, Bonvalot S, Gronchi A, Vanel D, Meyer M, Robinson P, Morosi C, Bloem JL, Terrier PH, Lazar A, Le Pechoux C, Wardelman E, Winfield JM, Boulet B, Bovee J, Haas RL (2016) Evaluation of response after pre-operative radiotherapy in soft tissue sarcomas; the European Organisation for Research and Treatment of Cancer-Soft Tissue and Bone Sarcoma Group (EORTC-STBSG) and Imaging Group recommendations for radiological examination and reporting with an emphasis on magnetic resonance imaging. Eur J Cancer 56: 37-44.

Meyer E, Delaney M, Lin Y, Morris A, Pavenski K, Tinmouth A, Murphy M, Slichter SJ, Heddle N, Dumont LJ (2013) A reporting guideline for clinical platelet transfusion studies from the BEST Collaborative. Transfusion 53(6): 1328-1334.

Miller AB, Hoogstraten B, Staquet M, Winkler A (1981) Reporting results of cancer treatment. Cancer 47(1): 207-214.

Moher D, Liberati A, Tetzlaff J, Altman DG (2009) Preferred reporting items for systematic reviews and meta-analyses: the PRISMA statement. J Clin Epidemiol 62(10): 1006-1012.

Moher D, Shamseer L, Clarke M, Ghersi D, Liberati A, Petticrew M, Shekelle P, Stewart LA (2015) Preferred reporting items for systematic review and meta-analysis protocols (PRISMA-P) 2015 statement. Syst Rev 4: 1 .

Moorcraft SY, Marriott C, Peckitt C, Cunningham D, Chau I, Starling N, Watkins D, Rao S (2016) Patients' willingness to participate in clinical trials and their views on aspects of cancer research: results of a prospective patient survey. Trials 17: 17.

Moore CM, Giganti F, Albertsen P, Allen C, Bangma C, Briganti A, Carroll P, Haider M, Kasivisvanathan V, Kirkham A, Klotz L, Ouzzane A, Padhani AR, Panebianco V, Pinto P, Puech P, Rannikko A, Renard-Penna R, Touijera K, Turkbey B, van Poppel H, Valdagni R, Walz J, Schoots I (2017) Reporting magnetic resonance imaging in men on active surveillance for prostate cancer: the PRECISE recommendations - a report of a European School of Oncology Task Force. Eur Urol 71(4): 648-655.

Nahum AM (1979) Biting the bullet: minimum standards for reporting cancer treatment statistics. Head Neck Surg 1(3): 201.

O’Brien BC, Harris IB, Beckman TJ, Reed DA, Cook DA (2014) Standards for reporting qualitative research: a synthesis of recommendations. Acad Med 89(9): 1245-1251.

Ogrinc G, Davies L, Goodman D, Batalden P, Davidoff F, Stevens D (2016) SQUIRE 2.0 (Standards for QUality Improvement Reporting Excellence): revised publication guidelines from a detailed consensus process. BMJ Qual Saf 25(12): 986-992.

Padhani AR, Lecouvet FE, Tunariu N, Koh DM, De Keyzer F, Collins DJ, Sala E, Schlemmer HP, Petralia G, Vargas HA, Fanti S, Tombal HB, de Bono J (2017) METastasis reporting and data system for prostate cancer: practical guidelines for acquisition, interpretation, and reporting of whole-body magnetic resonance imaging-based evaluations of multiorgan involvement in advanced prostate cancer. Eur Urol 71(1): 81-92.

Papathanasiou AA, Zintzaras E (2010) Assessing the quality of reporting of observational studies in cancer. Ann Epidemiol 20(1): 67-73.

Peron J, Maillet D, Gan HK, Chen EX, You B (2013) Adherence to CONSORT adverse event reporting guidelines in randomized clinical trials evaluating systemic cancer therapy: a systematic review. J Clin Oncol 31(31): 3957-3963.

Peron J, Pond GR, Gan HK, Chen EX, Almufti R, Maillet D, You B (2012) Quality of reporting of modern randomized controlled trials in medical oncology: a systematic review. J Natl Cancer Inst 104(13): 982-989.

Provenzano E, Bossuyt V, Viale G, Cameron D, Badve S, Denkert C, MacGrogan G, Penault-Llorca F, Boughey J, Curigliano G, Dixon JM, Esserman L, Fastner G, Kuehn T, Peintinger F, von Minckwitz G, White J, Yang W, Symmans WF (2015) Standardization of pathologic evaluation and reporting of postneoadjuvant specimens in clinical trials of breast cancer: recommendations from an international working group. Mod Pathol 28(9): 1185-1201.

Radvany MG, Murphy KJ, Millward SF, Barr JD, Clark TW, Halin NJ, Kinney TB, Kundu S, Sacks D, Wallace MJ, Cardella JF, Technology Assessment Committee of the Society of Interventional R (2009) Research reporting standards for percutaneous vertebral augmentation. $J$ Vasc Interv Radiol 20(10): 1279-1286.
Raghav KP, Mahajan S, Yao JC, Hobbs BP, Berry DA, Pentz RD, Tam A, Hong WK, Ellis LM, Abbruzzese J, Overman MJ (2015) From protocols to publications: a study in selective reporting of outcomes in randomized trials in oncology. J Clin Oncol 33(31): 3583-3590.

Rajkumar SV, Harousseau JL, Durie B, Anderson KC, Dimopoulos M, Kyle R, Blade J, Richardson P, Orlowski R, Siegel D, Jagannath S, Facon T, Avet-Loiseau H, Lonial S, Palumbo A, Zonder J, Ludwig H, Vesole D, Sezer O, Munshi NC, San Miguel J (2011) Consensus recommendations for the uniform reporting of clinical trials: report of the International Myeloma Workshop Consensus Panel 1. Blood 117(18): 4691-4695.

Reeve BB, McFatrich M, Pinheiro LC, Weaver MS, Sung L, Withycombe JS, Baker JN, Mack JW, Waldron MK, Gibson D, Tomlinson D, Freyer DR, Mowbray C, Jacobs S, Palma D, Martens CE, Gold SH, Jackson KD, Hinds PS (2017) Eliciting the child's voice in adverse event reporting in oncology trials: Cognitive interview findings from the Pediatric Patient-Reported Outcomes version of the Common Terminology Criteria for Adverse Events initiative. Pediatr Blood Cancer 64(3): e26261.

Rubino M, Pragnell MVC (1999) Guidelines for reporting case series of tumours of the colon and rectum. Tech Coloproctol 3(2): 93-97.

Salem R, Lewandowski RJ, Gates VL, Nutting CW, Murthy R, Rose SC, Soulen MC, Geschwind JF, Kulik L, Kim YH, Spreafico C, Maccauro M, Bester L, Brown DB, Ryu RK, Sze DY, Rilling WS, Sato KT, Sangro B, Bilbao JI, Jakobs TF, Ezziddin S, Kulkarni S, Kulkarni A, Liu DM, Valenti D, Hilgard P, Antoch G, Muller SP, Alsuhaibani H, Mulcahy MF, Burrel M, Real MI, Spies S, Esmail AA, Raoul JL, Garin E, Johnson MS, Benson 3rd AB, Sharma RA, Wasan H, Lambert B, Memon K,

Kennedy AS, Riaz A, Technology Assessment C, Interventional Oncology Task Force of the Society of Interventional R (2011) Research reporting standards for radioembolization of hepatic malignancies. J Vasc Interv Radiol 22(3): 265-278.

Scher HI, Eisenberger M, D'Amico AV, Halabi S, Small EJ, Morris M, Kattan MW, Roach M, Kantoff P, Pienta KJ, Carducci MA, Agus D, Slovin SF, Heller G, Kelly WK, Lange PH, Petrylak D, Berg W, Higano C, Wilding G, Moul JW, Partin AN, Logothetis C, Soule HR (2004) Eligibility and outcomes reporting guidelines for clinical trials for patients in the state of a rising prostate-specific antigen: recommendations from the Prostate-Specific Antigen Working Group. J Clin Oncol 22(3): 537-556.

Schulz KF, Altman DG, Moher D (2010) CONSORT 2010 statement: updated guidelines for reporting parallel group randomized trials. Ann Intern Med 152(11): 726-732.

Sekula P, Pressler JB, Sauerbrei W, Goebell PJ, Schmitz-Drager BJ (2016) Assessment of the extent of unpublished studies in prognostic factor research: a systematic review of p53 immunohistochemistry in bladder cancer as an example. BMJ open 6(8): e009972.

Sivendran S, Galsky MD (2016) Adverse event reporting in oncology clinical trials - lost in translation? Expert Opin Drug Saf 15(7): 893-896.

Slemc L, Kunej T (2016) Transcription factor HIF1A: downstream targets, associated pathways, polymorphic hypoxia response element (HRE) sites, and initiative for standardization of reporting in scientific literature. Tumour Biol 37(11): 14851-14861.

Stiles CR, Biondo PD, Cummings G, Hagen NA (2010) Clinical trials focusing on cancer pain educational interventions: core components to include during planning and reporting. J Pain Symptom Manage 40(2): 301-308.

Stout NK, Knudsen AB, Kong CY, McMahon PM, Gazelle GS (2009) Calibration methods used in cancer simulation models and suggested reporting guidelines. Pharmacoeconomics 27(7): 533-545.

Subramanian J, Simon R (2010) Gene expression-based prognostic signatures in lung cancer: ready for clinical use? J Natl Cancer Inst 102(7): 464-474.

Tam VC, Tannock IF, Massey C, Rauw J, Krzyzanowska MK (2011) Compendium of unpublished phase III trials in oncology: characteristics and impact on clinical practice. J Clin Oncol 29(23): 3133-3139.

Tong A, Sainsbury P, Craig J (2007) Consolidated criteria for reporting qualitative research (COREQ): a 32 -item checklist for interviews and focus groups. Int J Qual Health Care 19(6): 349-357. 
Unknown (1979) WHO Handbook for Reporting Results of Cancer treatment. WHO Handbook for Reporting Results of Cancer treatment Offset publication No.48.

Vera-Badillo FE, Napoleone M, Krzyzanowska MK, Alibhai SM, Chan AW, Ocana A, Seruga B, Templeton AJ, Amir E, Tannock IF (2016) Bias in reporting of randomised clinical trials in oncology. Eur J Cancer 61: 29-35.

Vickers AJ, Ballen V, Scher HI (2007) Setting the bar in phase II trials: the use of historical data for determining 'go/no go' decision for definitive phase III testing. Clin Cancer Res 13(3): 972-976.

von Elm E, Altman DG, Egger M, Pocock SJ, Gotzsche PC, Vandenbroucke JP (2007) Strengthening the Reporting of Observational Studies in Epidemiology (STROBE) statement: guidelines for reporting observational studies. BMJ 335(7624): 806-808.
Wendler JJ, Fischbach K, Ricke J, Jurgens J, Fischbach F, Kollermann J, Porsch M, Baumunk D, Schostak M, Liehr UB, Pech M (2016) Irreversible Electroporation (IRE): standardization of terminology and reporting criteria for analysis and comparison. Pol J Radiol 81: $54-64$.

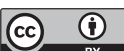

This work is licensed under the Creative Commons Attribution 4.0 International License. To view a copy of this license, visit http://creativecommons.org/licenses/by/4.0/

(C) The Author(s) named above 2018

Supplementary Information accompanies this paper on British Journal of Cancer website (http://www.nature.com/bjc) 